\title{
Dominik Mączyński
}

Adam Mickiewicz University in Poznań

mdominik@amu.edu.pl

\section{The BEPS Influence on Tax Information Exchange}

\author{
Wpływ projektu BEPS na wymianę informacji podatkowych
}

\begin{abstract}
SUMMARY
None of the actions envisaged in the Action Plan on BEPS directly relies on intensifying the exchange of information on tax matters. By developing the Action Plan on BEPS, the OECD has identified areas of tax law that have noticed the need for some changes. However, the objectives set out in the Action Plan on BEPS will not be achieved without significantly improving the exchange of information on tax matters between the tax administrations.

For several years, a significant breakthrough in the field of exchange of information on tax matters has been observed. Firstly, Agreements on Exchange of Information on Tax Matters are increasingly important. Secondly, the role of the Convention on Mutual Administrative Assistance in Tax Matters has significantly increased. Thirdly, the Action Plan on BEPS itself needs to step up its activities in the field of exchange of information on tax matters. The Action 5, countering harmful tax practices more effectively, taking into account transparency and substance, highlighted the need to improve transparency, including the mandatory spontaneous exchange of information on tax matters, while the implementation of the objectives described in the Action 13 referring to transfer pricing documentation and country-by-country reporting calls for the development of an automatic exchange of information on tax matters. Therefore, there is no doubt that effective exchange of information on tax matters is one of the tools without which implementation of the Action Plan on BEPS will be significantly impeded.
\end{abstract}

Keywords: tax; tax avoidance; exchange of information on tax matters; Action Plan on BEPS

\section{INTRODUCTION}

None of the actions foreseen in the Base Erosion and Profit Shifting Action Plan (hereinafter referred to as the BEPS Project) ${ }^{1}$ refers directly to intensifying the tax information exchange. While developing the Project, the OECD identified

1 Action Plan on Base Erosion Profit Shifting, www.oecd.org/tax/beps/beps-actions.htm [access: 10.03.2018]. 
tax law areas in which specific amendments are required. Fifteen areas were presented in which the proposed amendments are supposed to eliminate - or at least reduce - tax income losses. Despite the fact that the information exchange was not considered as one of the target areas of the BEPS Project, the objectives included therein will not be accomplished without a considerable upgrading of the tax data transfer between the competent organs of particular countries ${ }^{2}$. Improving the tax information exchange should be conducted at least at two levels. Firstly, extending the subjective scope of countries having tax jurisdiction engaged in tax information exchange is desirable. Secondly, Action 5 devoted to countering harmful tax practices implies the need for improving transparency of taxable transactions, including the mandatory spontaneous exchange of information on decisions with regard to preferential fiscal treatment achieved by taxpayers. In this context, it should be noted that accomplishing the objectives provided for in the Action 13, referring to transfer pricing documentation and country-by-country reporting, requires developing the automatic exchange of information on tax matters.

The publication is based on a fundamental assumption that the international information exchange constitutes a necessary condition for efficiency of actions aimed at reducing tax base erosion. In connection with economic processes being globalised, efficient taxation is not possible within the framework of exclusively one jurisdiction. The cooperation between organs of particular countries is indispensable, as the result of which is to receive the data necessary for both a proper tax assessment and an efficient tax withholding. In consequence, the role of information exchange is still on the increase. The number of jurisdictions joining the cooperation is growing, and new forms of information exchange are being developed, the latter of which do not encompass merely tax information exchange with directly affiliated entities, to whom the exchange refers, but also those which incorporate mutual notifications between countries regarding settlements granting tax advantages to the given entities.

The basic thesis that requires verification is the claim that the BEPS Project has significantly contributed to the intensification of the international exchange of information on tax matters, both in subjective and objective terms. As a result, the aim of this article is to examine as to which degree the BEPS Project impacts the scope and forms of the tax information exchange. Accomplishing this task consists in presenting the present principles on which the information exchange between administrative organs of particular countries is based. In this context, it is possible to analyse the BEPS Project from the angle of proposals formulated therein that aim at modifying the present scope and forms of tax information exchange. Examining

2 See also: B. Kuźniacki, Wymiana informacji podatkowych z innymi państwami - nowa era stosowania prawa podatkowego w wymiarze międzynarodowym. Wymiana na wniosek i z urzędu (1), „Przegląd Podatkowy” 2017, nr 5, p. 17. 
those areas will allow for indicating consequences stemming from the BEPS Project for the exchange of information on tax matters.

\section{PRINCIPLES REGARDING TAX INFORMATION EXCHANGE PRIOR TO BEPS}

Both currently and before developing the BEPS Project, the international tax information exchange has been based on the international, European and domestic law.

The provisions concerning tax information exchange are provided for in bilateral agreements on double taxation, the structures of which are similar to one another due to the fact that those agreements are based on the OECD Model Convention on Income and Capital ${ }^{3}$. Nevertheless, the information exchange with merely such a basis encounters considerable restrictions. The data is made accessible exclusively by the countries with which Poland has already regulated the international tax relations. It is also noteworthy that the first version of the agreement on avoiding double taxation in matters of income and capital ${ }^{4}$ concluded between the Republic of Poland and the Swiss Confederation does not provide the possibility of tax information exchange. It was not until Article 25a was added thereto that both countries started cooperating in this matter ${ }^{5}$. Moreover, only few agreements concluded by Poland constituted a legal basis for the exchange of information covered by banking secrecy ${ }^{6}$.

The Multilateral Convention on Mutual Administrative Assistance in Tax Matters (hereinafter referred to as Multilateral Convention) ${ }^{7}$ has also had a significant meaning for the tax information exchange. The Multilateral Convention encompasses legal basis for the tax information exchange in a number of forms, including:

\footnotetext{
3 Poland has concluded 93 double taxationagreements. See: Wykazumów ounikaniu podwójnego opodatkowania, www.finanse.mf.gov.pl/pl/abc-podatkow/umowy-miedzynarodowe/wykaz-umow-o-unikaniu-podwojnego-opodatkowania/-/asset_publisher/d3oA/content/wykaz-umow-o-unikaniu-podwojnego-opodatkowania?_101_INSTANCE_d3oA_redirect=http $\% 3 \mathrm{~A} \% 2 \mathrm{~F} \% 2 \mathrm{Fwww}$. finanse.mf.gov. $\mathrm{pl} \% 2 \mathrm{Fpl} \% 2 \mathrm{Fabc}$-podatkow\%2Fumowy-miedzynarodowe $\% 2 \mathrm{Fwykaz}$-umow-o-unikaniu-podwojnego-opodatkowania\%3Fp_p_id\%3D101_INSTANCE_d3oA\%26p_p_lifecycle\%3D0\%26p_p_ state $\% 3$ Dnormal\%26p_p_mode $\% 3$ Dview\%26p_p_col_id $\% 3$ Dcolumn-2\%26p_p_col_

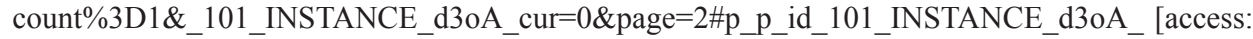
11.03.2108].

4 The Convention between the Republic of Poland and the Swiss Confederacy on Avoiding Double Taxation in Matters of Income and Capital concluded in Bern as of 2 September 1991 (Journal of Laws 1993, No. 22, Item 92 as amended).

5 See: The Protocol between the Republic of Poland and the Swiss Confederacy on the Amendment of the Convention the Republic of Poland and the Swiss Confederacy on Avoiding Double Taxation in Matters of Income and Capital concluded in Bern as of 2 September 1991 and the Protocol drawn up in Bern as of 2 September 1991 made in Warsaw as of 20 April 2010 (Journal of Laws 2011, No. 255, Item 1533).

6 D. Mączyński, Międzynarodowa wspótpraca w sprawach podatkowych, Warszawa 2009, p. 251.

7 The Convention on Mutual Administrative Help in Tax Matters as of 25 January 1988, ratified by Poland as of 19 May 1997 (Journal of Laws 1998, No. 141, Item 913-914).
} 
automatic, spontaneous information exchange as well as the one performed on request. Despite a potentially widely outlined scope of tax information exchange, for a long time, the cooperation within the Multilateral Convention did not constitute an efficient tool applied by financial administrative organs of particular countries. It resulted mainly from the restricted objective scope of the Agreement. Up until 2012, the Multilateral Convention was signed by 43 tax jurisdictions ${ }^{8}$. Furthermore, the Multilateral Convention mainly created space in which it was possible to start cooperation, but it did not include mechanisms allowing for measures to be directly taken. As a result, the efficient cooperation occurred in the form of tax information exchange on request. In case of the automatic information exchange, consisting in a periodic sending of the given data by the administration of one country to the appropriate organ of another country, two requirements had to be met. Firstly, the administration organs of particular countries ought to specifically determine the scope of the information to be exchanged. Secondly, the automatic information exchange required the unification of electronic formats applied for data transfer. The major drawback of the Multilateral Convention was the lack of the objective scope and the procedure in which the automatic information exchange was to be conducted. This question was supposed to be settled bilaterally by the countries. As a consequence, the Multilateral Convention does not impose the obligation to start such a cooperation on the countries concluding this agreement, allowing the countries to exchange information only with countries selected among those, which entered it. On the other hand, the spontaneous tax information exchange, consisting in transferring data without a prior motion submitted by another country, required a proper identification of premises justifying the act of making the data accessible. The Party to the Multilateral Convention is obliged to transfer tax information, provided there is a justified suspicion that: tax loss occurs in another country; a taxpayer makes use of tax advantage that may result in arising or increasing the tax liability in another country; trade transactions are conducted in at least two countries in such a manner that it may result in tax revenues being reduced; it is suspected that lower tax obligations may be a consequence of a fictional profit shifting within a group of enterprises and the transferred information may be essential for the purpose of determining the tax liability in the territory of another country. Hence, the efficiency of the spontaneous tax information exchange is dependent upon the extent to which the financial administration of a given country is able to identify the data significant to the taxation process in other countries.

8 Jurisdictions participating in the convention on mutual administrative assistance in tax matters, 18 May 2018, www.oecd.org/tax/exchange-of-tax-information/Status_of_convention.pdf [access: 04.05.2018]. The current list of the Convention Signatories amounts to 113 tax jurisdictions. 
The Agreements on Tax Matters are also considered a legal basis of the tax information exchange ${ }^{9}$. The Model Agreement was developed by the Working Group on Effective Information Exchange of the OECD World Forum, which included representatives of the OECD member states and representatives of other countries or territories (Aruba, Bermuda, Bahrain, the Cayman Islands, Cyprus, Isle of Man, Malta, Mauritius, the Netherlands Antilles, the Seychelles and San Marino) ${ }^{10}$. The OECD Report on Harmful Tax Competition triggered developing the content of the Model Agreement ${ }^{11}$. The Report indicated that one of the basic causes of the harmful tax competition was the lack of effective information exchange. The essence of the Agreement boils down to information exchange with countries applying the harmful tax competition. Its rudimentary restriction stems from the lack of basis allowing for introducing the automatic information exchange.

In accordance with the European law, the scope and the forms of tax information are dependent on the kind of taxes to which this information refers. The basis of the cooperation within the value added tax constitutes the Council Regulation (EU) No. 1798/2003 of 7 October 2003 on administrative cooperation and combating fraud in the field of value added tax as well as the repealing Regulation (EEC) No. $218 / 92^{12}$. The tax information exchange for the needs of excise duties performed until 1 July 2012 was undertaken on the basis of the Council Regulation (EU) No. $389 / 2012$ of 2 May 2012 on administrative cooperation in the field of excise duties and the repealing Regulation (EC) No. 2073/2004 ${ }^{13}$.

The information exchange regarding direct taxation is performed on the basis of the Council Directive of 19 December 1977 concerning mutual assistance by the competent authorities of the Member States in the field of direct taxation ${ }^{14}$, and from 1 January 2013 on the basis of the Council Directive 2011/16/EU of 15

9 So far, Poland has concluded 15 agreements on tax information exchange. See: Wykaz umów o wymianie informacji w sprawach podatkowych, www.finanse.mf.gov.pl/pl/abc-podatkow/ umowy-miedzynarodowe/wykaz-umow-o-wymianie-informacji-w-sprawach-podatkowych [access: 11.03.2018].

10 D. Mączyński, op. cit., p. 211.

11 OECD Report, Harmful Tax Competition: An Emerging Global Issue, 1998, www.oecd.org/ dataoecd/33/1/1904184.pdf [access: 11.03.2018].

12 The Council Regulation (EC) No. 1798/2003 of 7 October 2003 on administrative cooperation in the field of value added tax and repealing Regulation (EEC) No. 218/92 (OJ L 264, 15.10.2003, pp. 1-11).

13 The Council Regulation (EU) No. 389/2012 of 2 May 2012 on administrative cooperation in the field of excise duties and repealing Regulation (EC) No. 2073/2004 (OJ L 121, 08.05.2012, pp. 1-15). Up to 30 June 2012, the legal basis for information exchange with regard to excise duty was the Council Regulation (EC) No. 2073/2004 of 16 November 2004 on administrative cooperation in the field of excise duties and repealing Regulation (EC) No. 2073/2004 (OJ L 359, 04.12.2004, pp. 1-10).

14 The Council Directive of 19 December 1977 concerning mutual assistance by the competent authorities of the Member States in the field of direct taxation (OJ L 336, 27.12.1977, as amended, pp. 15-20) - the Directive lost its binding legal force on 31 December 2012. 
February 2011 on administrative cooperation in the field of taxation and repealing Directive 77/799/EEC (hereinafter referred to as Council Directive 2011/16/EU) ${ }^{15}$.

In the domestic law, the basis of the international tax information exchange was until 3 July 2017 - constituted particularly by provisions included in Chapter VIIa of the Tax Ordinance $\mathrm{Act}^{16}$. They guaranteed the possibility of transferring data owned by financial institutions (as banking secrecy ceased to be an obstacle for information exchange), as well as confidentiality of the transferred information, moreover, they specified the principles of tax information exchange with the European member states. The tax information exchange encompassed all kinds of information relevant to a proper determination of tax base and the amount of tax liability with regard to: taxation of income, assets or capital, regardless of the taxation manner of form, including income taxation arising from the sale of products or property rights as well as the increase of the value of assets or capital, excise duty on mineral oils, alcohol, alcoholic beverages, tobacco products and taxation of insurance contributions. The information could be provided for ex officio or upon the motion of foreign organs.

In the context of the tax information exchange, the following legal acts should be mentioned: the Agreement between the Government of the Republic of Poland and the Government of the United States of America on the Improvement of International Tax Compliance and the Implementation of FATCA Legislation ${ }^{17}$ and the Act of 9 October 2015 on the Enforcement of the Agreement between the Government of the United States of America and the Government of the Republic of Poland on the Improvement of International Tax Compliance and the Implementation of FATCA Legislation ${ }^{18}$. The Agreement was signed after developing the BEPS Project, however, the conclusion of the former one cannot be considered as stemming directly from the recommendations included in the Project. These both legal acts - the Agreement and the Act enforcing it - constitute a basis for the automatic tax information exchange in the scope specified therein ${ }^{19}$. In this way, they undoubtedly create an exceptional

15 The Council Directive 2011/16/EU of 15 February 2011 on administrative cooperation in the field of taxation and repealing Directive 77/799/EEC (OJ L 64, 11.03.2011, as amended, pp. 1-12).

16 The Act of 29 August 1997 Tax Ordinance (Journal of Laws 2015, Item 613 as amended), in the wording valid up to 3 April 2017.

17 The Agreement between the Government of the Republic of Poland and the Government of the United States of America on the Improvement of International Tax Compliance and the Implementation of FATCA Legislation as well as its Final Arrangements in the form of Memorandum of Understanding, signed on 7 October 2014 in Warsaw (Journal of Laws of 2015, Item 1647).

18 The Act of 9 October 2015 on the Enforcement of the Agreement between the Government of the United States of America and the Government of the Republic of Poland on the Improvement of International Tax Compliance and the Implementation of FATCA Legislation (Journal of Laws 2017, Item 1858).

19 More: F. Majdowski, M. Wilczkiewicz, Polska podpisała umowe w sprawie FATCA, „Przegląd Podatkowy” 2015, nr 5, pp. 19-25; W. Missala, FATCA, czyli amerykański podatek obciązajacy polskie podmioty, „Przegląd Podatkowy”2012, nr 5, pp. 9-14. 
position for the United States of America as regards the access to information, which scope and accessibility manner exceed the standard international relations, the compliance to which Poland has committed itself with other countries ${ }^{20}$.

\section{IMPLEMENTATION MANNERS OF PROPOSALS INCLUDED IN BEPS WITHIN TAX INFORMATION EXCHANGE}

The BEPS Project, putting forward specific actions indispensable for reducing tax base erosion and profit shifting and, in consequence, reducing the tax income losses, does not constitute a law source either within the meaning of Article 87 of the Constitution of the Republic of Poland ${ }^{21}$ or the international law. The OECD is not competent to enact the binding tax law norms. In consequence, the OECD Reports, recommendations and other documents issued by the OECD do not have a binding power, and thus, do not oblige the member states and other non-member countries to create tax law based on those documents. Nevertheless, the lack of ability to enact the binding tax law norms does not deprive this organisation from the considerable impact on the content of the tax international law. In spite of the fact that the OECD member states have not transferred any entitlements to enact law in any area to this international institution, its role cannot be underrated. The legislative role of the OECD is related to its impact on the international tax law form in connection with its analytical activity as well as drawing up of sample documents, which constitute a source for countries intending to regulate their international relations. Furthermore, the fact that the OECD recommendations are an expression of compromise and that they express intentions of the countries united in this organisation towards undertaking coordinated measures counteracting tax frauds, must not be disregarded. In consequence, the OECD efficiency is based on both its own authority in the field of the international tax law and the willingness of its member states, which is expressed in documents developed by those countries.

Thus, accomplishing the BEPS objectives requires undertaking particular legislative measures aiming at the implementation of the actions put forward in the Project to the legal order within the scope in which those actions do not constitute binding legal norms any more. It should be noted that the BEPS Project is a document of a general character, addressed to all countries that express their willingness to implement the actions provided for therein. With regard to particular countries or a group of countries, it may turn out, though, that the recommendations included in BEPS are an integral part of a domestic legal order. When the domestic law or

\footnotetext{
20 Also: B. Kuźniacki, Wymiana informacji podatkowych z innymi państwami... (1), p. 15.

21 Constitution of the Republic of Poland of 2 April 1997 (Journal of Laws, No. 78, Item 483 as amended).
} 
the valid tax agreement reflects proposals included in the BEPS Project, no legislative measures are required. Hence, it may turn out that with regard to some tax jurisdictions, introducing the BEPS proposals may be connected with considerable amendments to legislation, whereas with regard to other countries, the necessary amendments will have a more restricted scope.

Implementing the BEPS guidelines may occur at both the international law and the domestic legal system levels. Bilateral agreements on income and capital are a basic tool in the international tax law. Numerous proposals put forward in BEPS may be introduced through the amendments already included in the Convention or through negotiating new tax agreements. However, taking into account a huge number of bilateral tax agreements based on the OECD Convention Model, any attempts aimed at amending them require considerable effort, determination and willingness of particular countries. Even assuming the best willingness of those countries, the negotiation process of the amendments to the valid agreements as well as concluding new conventions should be considered in the perspective of at least several years. However, adopting such a measure does not guarantee succeeding in introducing the BEPS Project. First and foremost, it is the case due to the fact that a gradual implementation of a given measure to the international tax law results in tax dichotomy and, consequently, opens up space for tax avoidance in particular transactions. It is possible that entities may make use of the fact that the BEPS recommendations have been adopted in relations between particular countries, whereas there are still measures in relations between other countries or a group of countries that require amendments pursuant to BEPS. Furthermore, even a successful process of amending international tax agreements does not guarantee the consistency of the solutions specified therein. For instance, it may turn out that adopting various measures aimed at the BEPS implementation will leave space for tax optimisation against the intention of the countries concluding agreements.

Therefore, signing (on 7 June 2017) the multilateral agreement referred to as the Multilateral Instrument (MLI), put forward in Action 15 of the BEPS Project, should be assessed positively ${ }^{22}$. Such an international tax law instrument has two considerable advantages ${ }^{23}$. Firstly, it enables a swift implementation of the BEPS proposals by a multitude of countries. Secondly, it allows for adopting adequate solutions by the countries that decide upon concluding such an agreement. However, a bilateral tax agreement is not free from drawbacks. They arise mostly from

22 So far, the Convention has been signed by 78 countries, including Poland. Six further jurisdictions expressed their willingness to sign the agreement. See: Signatories and parties to the multilateral convention to implement tax treaty related measures to prevent base erosion and profit shifting, 22 March 2018, www.oecd.org/tax/treaties/beps-mli-signatories-and-parties.pdf [access: 11.04.2018].

23 More about the Multilateral Convention: M. Leconte, M. Raińczuk, Konwencja Wielostronna (BEPS działanie nr 15) - omówienie najistotniejszych zagadnień, „Monitor Podatkowy” 2017, nr 5, pp. 16-21. 
the fact that a multilateral instrument, by definition, is not to replace the already existing tax agreements but to complement them. Therefore, the complexity level of the international tax law enforcement will increase. Specifying the content of the international tax law norm will require examining both the bilateral agreement concluded between particular countries and the multilateral agreement, amending the former one. It should be also noted that despite concluding the multilateral agreement by the countries, it will start to have effect in relations between particular countries in various periods of time, which will be a consequence of the duration of the domestic ratification procedure. Moreover, the countries are not obliged to introduce all provisions of the Convention. The minimum standard requires of a country entering the agreement to apply merely three provisions (Article 6,7 and 16). Eventually, countries-signatories of the agreement are entitled to submit objections, notifications, selections of facultative or alternative options provided for therein as well as declarations on applying solutions included therein ${ }^{24}$. All those exceptions give rise to a presumption that the legal status at the international level will become considerably more complex.

When analysing the question of the BEPS Project implementation, it is indispensable to mention domestic legal measures as well. A considerable part of proposals resulting from the BEPS Project may be implemented through methods typical for domestic legal orders. In numerous areas, it is possible to undertake legislative activity for the purpose of revision of the already existing regulations or introducing new solutions to the substantive and procedural tax law.

\section{AMENDMENTS TO THE PRINCIPLES OF TAX INFORMATION EXCHANGE IMPACTED BY BEPS}

As mentioned above, none of the actions provided for in the BEPS Project refers directly to intensifying the tax information exchange. Nevertheless, the information exchange is a significant tool in counteracting the tax base erosion and profit shifting. Thus, upgrading of the tax information exchange has become a significant task in the process of introducing objectives specified in the BEPS Project. The trigger of the automatic information exchange can be found mostly in Action 13 of the BEPS Project, which concerns documenting transfer pricing and

${ }^{24}$ Poland made use of the entitlement to submit objections, notifications, selections of facultative or alternative options provided for therein as well as declarations on applying solutions included therein. See: The Draft Act on Ratification of the Multilateral Agreement implementing the Treaty Tax Law aimed at counteracting the Tax Base Erosion and Profit Shifting, drawn up in Paris on 24 November 2016, http://orka.sejm.gov.pl/Druki8ka.nsf/0/39B2431FBC225D03C12581670038E84D/\%24File/1776.pdf [access: 11.02.2018]. 
country-by-country reporting. However, implementing the objectives described in Action 5, entitled Countering Harmful Tax Practices More Effectively, Taking into Account Transparency and Substance, referring to transactions, considerably facilitates upgrading the principles of the obligatory and spontaneous tax information exchange.

The implementation of Action 13 of the BEPS Project referring to documenting transfer pricing and country-by-country reporting has impacted the dynamic development of the automatic exchange of information on tax matters in the recent years ${ }^{25}$. As a consequence of the measures put forward in the BEPS Project, in 2014, the OECD and countries united within the G20 adopted the Common Reporting Standard, which is supposed to be considered a basis for the automatic tax information exchange. In the Final Report of Action 13, a model legislation was put forward, which would allow countries for introducing the objectives of the Project that encompasses the principles of the exchange of information regarding multinational enterprises ${ }^{26}$. Furthermore, three models of agreements on information reporting between competent organs of particular countries were developed: Multilateral Competent Authority Agreement on the Exchange of Country-by-Country Reports $^{27}$, which refers to the provisions of the Multilateral Convention, Competent Authority Agreement on the Exchange of Country-by-Country Reports on the Basis of a Double Tax Convention ${ }^{28}$ and Competent Authority Agreement on the Exchange of Country-by-Country Reports on the Basis of Tax Information Exchange Agreement ${ }^{29}$.

Regardless of that, within the automatic tax information exchange, the data concerning foreign bank accounts is supposed to be transferred to the competent organs of the account holder's residence country. So far, 102 countries have adopted the common reporting standard, 49 of which have obliged themselves to start exchanging the information in September 2017, and the rest (53 jurisdictions) - in September $2018^{30}$. The tax information exchange occurs mostly pursuant to Article 6 of the Multilateral Convention. Based on this provision, the Multilateral Competent Authority Agreement on Automatic Exchange of Financial Account Information

25 See also: A. Wieśniak-Wiśniewska, M. Czerwiński, Świat podatków po projekcie BEPS i jego wpływ na polskich podatników, „Przegląd Podatkowy” 2016, nr 6, p. 30.

26 Transfer Pricing Documentation and Country-by-Country Reporting, Action 13 - 2015 Final Report, www.keepeek.com/Digital-Asset-Management/oecd/taxation/transfer-pricing-documentation-and-country-by-country-reporting-action-13-2015-final-report_9789264241480-en\#.WeIpTGi0PIU [access: 10.05.2018], pp. 39-43.

${ }^{27}$ Ibidem, pp. 45-51.

28 Ibidem, pp. 59-63.

29 Ibidem, pp. 65-69.

30 www.oecd.org/tax/automatic-exchange/news/first-automatic-crs-exchanges-between-49-jurisdictions-to-take-place-over-2000-bilateral-exchange-relationships-in-place.htm [access: 10.05.2018]. 
has been developed ${ }^{31}$. The Agreement has been signed by 95 countries so far ${ }^{32}$. Alternatively, as a legal basis for information exchange, the countries may apply the provisions of bilateral tax agreements as well as agreements on tax information exchange concluded with countries applying harmful tax competition.

The Project introduction is based on a conviction concerning the need of the countries' mutual notifications about granting given tax rulings to taxpayers, whereby it should be emphasised that issuing a tax ruling to a taxpayer is considered a negative phenomenon. The idea of information exchange boils down to an attempt to avoid a situation in which the lack of knowledge about a taxpayer's tax situation in one country poses a risk of tax reduction in another country. These tax rulings may be encountered in various forms and are widely defined in the Final Report of Action 5. In the Report it was indicated that the very term "tax ruling" is to be understood as all kinds of advice, information or measures implemented by tax organs towards a taxpayer or a group of taxpayers, confirming their tax situation (position) to which taxpayers may refer ${ }^{33}$. The determination of implementing the BEPS Project is reflected in the fact that the tax information exchange scope is supposed to encompass not only rulings to be adopted in the future but also the ones issued prior to developing the BEPS Project. In the Final Report, it is recommended that object of the information exchange should be tax rulings issued before 1 January 2010 and having effect after 1 January 2014. In the case of future tax rulings (issued after 1 January 2016), it is recommended that the countries gain information allowing for identifying the country, to which the information is supposed to be made accessible, due to the potential risk of its tax income reduction.

\section{CONCLUSIONS}

The legal bases of the information exchange prior to the BEPS Project were complex and encompassed provisions listed in international agreements, European Union law as well as domestic legislation of particular countries. They allowed for information exchange in three rudimentary forms: automatic, spontaneous, and on

31 www.oecd.org/tax/automatic-exchange/international-framework-for-the-crs/multilateral-competent-authority-agreement.pdf [access: 10.05.2018].

32 Signatories of the multilateral competent authority agreement on automatic exchange of financial account information and intended first information exchange date, 15 January 2018, www. oecd.org/tax/automatic-exchange/international-framework-for-the-crs/MCAA-Signatories.pdf [access: 11.02 .2018$]$.

33 Countering Harmful Tax Practices More Effectively, Taking into Account Transparency and Substance, Action 5 - 2015 Final Report, www.keepeek.com/Digital-Asset-Management/oecd/taxation/countering-harmful-tax-practices-more-effectively-taking-into-account-transparency-and-substance-action-5-2015-final-report_9789264241190-en\#.WeIu6Gi0PIU [access: 10.05.2018], p. 47. 
request. The competent tax organs were able to gain and obliged to enable access to the information that concerned the most relevant taxes, including: income tax, value added tax, and excise duty tax. Thus, the legal status within the tax information exchange prior to introducing the BEPS Project did not require any considerable upgrading. Facilitating this process did not constitute a problem in itself, which would have been identified as a yet separate area requiring introducing relevant revisions. Moreover, it was a result of the fact that the efficient information exchange was not considered an objective but an indispensable tool towards achieving the results foreseen in the BEPS Project. The need to intensify the information exchange in areas, whose upgrading could contribute to the implementation of Actions 13 and 5 of the BEPS Project, was, therefore, noticed.

In the former case, coercing countries to automatically exchange tax information that refers to multinational concerns is supposed to safeguard them against tax fraud resulting from transfer pricing mechanism. It has been noticed that the lack of information exchange between countries creates space for tax optimisation for affiliated entities, which means reducing tax base for the countries, thus, reducing tax income. Reporting the given data by enterprises, followed by exchanging the information gathered in such a manner, is supposed to guarantee an efficient control over the income transfer between the countries. It seems that the automatic tax information exchange constitutes a proper tool in this regard, allowing for accomplishing given objectives.

However, with regard to Action 5, it was put forward in the BEPS Project that the role of the obligatory tax information exchange, encompassing the data on the tax rulings granted to a taxpayer or a group of taxpayers, should be extended. In this case, it is vital to assume that an acknowledgement of a given entity's tax situation in the form of a tax interpretation or a similar legal equivalent thereof does not constitute a preferential tax regime. The aim of the spontaneous tax information exchange is not to restrict this kind of a tax tool but to enable accessibility to the information regarding a taxpayer's favourable tax situation to another country, so that this tax advantage could be taken into account in the taxation process in the territory of another country. Therefore, the essence of the recommendation set forth in the BEPS Project boils down to applying the tax information exchange as a tool publicising measures taken by particular countries towards particular taxpayers or groups of taxpayers in the countries, in which this information may impact the taxation scope.

Implementing the BEPS recommendations within the principles of tax information in Poland occurs at both an international and a domestic level. Poland is a party to the Multilateral Convention, the role of which - also with regard to the scope of tax information exchange - grows accordingly to the increase of a number of signatory countries thereto. Poland entered the Multilateral Competent Authority Agreement on Automatic Exchange of Financial Account Information, thus undertaking an obligation to exchange information since September 2017. Moreover, it 
should be noticed that since 1 January 2013, Poland concluded 7 further agreements on tax information exchange ${ }^{34}$.

Based on the domestic legislation, the Act of 9 March 2017 on the Tax Information Exchange with Other Countries ${ }^{35}$ is essential for the tax exchange process, as it expresses - first and foremost - implementing the Council Directive 2011/16/ EU. Nevertheless, it is noteworthy that the scope regulating the principles of the automatic tax information exchange on tax interpretations and decisions on transactional prices (Part IV) as well as tax information exchange on entities being parts of a group of entities (Part V) encompasses recommendations resulting from the BEPS Project as well ${ }^{36}$.

\section{REFERENCES}

Action Plan on Base Erosion Profit Shifting, www.oecd.org/tax/beps/beps-actions.htm [access: 10.03.2018].

Constitution of the Republic of Poland of 2 April 1997 (Journal of Laws, No. 78, Item 483 as amended).

Countering Harmful Tax Practices More Effectively, Taking into Account Transparency and Substance, Action 5 - 2015 Final Report, www.keepeek.com/Digital-Asset-Management/oecd/taxation/ countering-harmful-tax-practices-more-effectively-taking-into-account-transparency-and-substance-action-5-2015-final-report_9789264241190-en\#.WeIu6Gi0PIU [access: 10.05.2018].

Jurisdictions participating in the convention on mutual administrative assistance in tax matters, 18 May 2018, www.oecd.org/tax/exchange-of-tax-information/Status_of_convention.pdf [access: 04.05.2018].

Kuźniacki B., Wymiana informacji podatkowych z innymi państwami-nowa era stosowania prawa podatkowego $w$ wymiarze międzynarodowym. Wymiana na wniosek $i$ z urzędu (1), „Przegląd Podatkowy" 2017, nr 5.

Kuźniacki B., Wymiana informacji podatkowych z innymi państwami - nowa era stosowania prawa podatkowego w wymiarze międzynarodowym. Wymiana informacji o rachunkach finansowych, interpretacjach podatkowych oraz informacji o jednostkach z grupy (2), „Przegląd Podatkowy” 2017, $\mathrm{nr} 6$.

Leconte M., Raińczuk M., Konwencja Wielostronna (BEPS działanie nr 15) - omówienie najistotniejszych zagadnień, „Monitor Podatkowy” 2017, nr 5.

Majdowski F., Wilczkiewicz M., Polska podpisała umowę w sprawie FATCA, „Przegląd Podatkowy” 2015, $\mathrm{nr} 5$.

Mączyński D., Międzynarodowa wspótpraca w sprawach podatkowych, Warszawa 2009.

34 With Belize, Bermuda, the British Virgin Islands, Gibraltar, the Cayman Islands, Liberia, the Commonwealth of the Bahamas. See: Wykaz umów o wymianie informacji w sprawach podatkowych.

35 The Act of 9 March 2017 on the Tax Information Exchange with Other Countries (Journal of Laws 2017, Item 648).

36 B. Kuźniacki, Wymiana informacji podatkowych z innymi państwami - nowa era stosowania prawa podatkowego w wymiarze międzynarodowym. Wymiana informacji o rachunkach finansowych, interpretacjach podatkowych oraz informacji o jednostkach z grupy (2), „Przegląd Podatkowy” 2017, nr 6, p. 17 ff. 
Missala W., FATCA, czyli amerykański podatek obciążający polskie podmioty, „Przegląd Podatkowy” 2012, $\mathrm{nr} 5$.

OECD Report, Harmful Tax Competition: An Emerging Global Issue, 1998, www.oecd.org/dataoecd/33/1/1904184.pdf [access: 11.03.2018].

Signatories of the multilateral competent authority agreement on automatic exchange of financial account information and intended first information exchange date, 15 January 2018, www. oecd.org/tax/automatic-exchange/international-framework-for-the-crs/MCAA-Signatories.pdf [access: 11.02.2018].

Signatories and parties to the multilateral convention to implement tax treaty related measures to prevent base erosion and profit shifting, 22 March 2018, www.oecd.org/tax/treaties/beps-mli-signatories-and-parties.pdf [access: 11.04.2018].

The Act of 29 August 1997 Tax Ordinance (Journal of Laws 2015, Item 613 as amended), in the wording valid up to 3 April 2017.

The Act of 9 October 2015 on the Enforcement of the Agreement between the Government of the United States of America and the Government of the Republic of Poland on the Improvement of International Tax Compliance and the Implementation of FATCA Legislation (Journal of Laws 2017, Item 1858).

The Act of 9 March 2017 on the Tax Information Exchange with Other Countries (Journal of Laws 2017, Item 648).

The Agreement between the Government of the Republic of Poland and the Government of the United States of America on the Improvement of International Tax Compliance and the Implementation of FATCA Legislation as well as its Final Arrangements in the form of Memorandum of Understanding, signed on 7 October 2014 in Warsaw (Journal of Laws of 2015, Item 1647).

The Convention on Mutual Administrative Help in Tax Matters as of 25 January 1988, ratified by Poland as of 19 May 1997 (Journal of Laws 1998, No. 141, Item 913-914).

The Convention between the Republic of Poland and the Swiss Confederacy on Avoiding Double Taxation in Matters of Income and Capital concluded in Bern as of 2 September 1991 (Journal of Laws 1993, No. 22, Item 92 as amended).

The Council Directive of 19 December 1977 concerning mutual assistance by the competent authorities of the Member States in the field of direct taxation (OJ L 336, 27.12.1977, as amended, pp. 15-20) - the Directive lost its binding legal force on 31 December 2012.

The Council Directive 2011/16/EU of 15 February 2011 on administrative cooperation in the field of taxation and repealing Directive 77/799/EEC (OJ L 64, 11.03.2011, as amended, pp. 1-12).

The Council Regulation (EC) No. 1798/2003 of 7 October 2003 on administrative cooperation in the field of value added tax and repealing Regulation (EEC) No. 218/92 (OJ L 264, 15.10.2003, pp. 1-11).

The Council Regulation (EU) No. 2073/2004 of 16 November 2004 on administrative cooperation in the field of excise duties and repealing Regulation (EC) No. 2073/2004 (OJ L 359, 04.12.2004, pp. 1-10).

The Council Regulation (EU) No. 389/2012 of 2 May 2012 on administrative cooperation in the field of excise duties and repealing Regulation (EC) No. 2073/2004 (OJ L 121, 08.05.2012, pp. 1-15).

The Draft Act on Ratification of the Multilateral Agreement implementing the Treaty Tax Law aimed at counteracting the Tax Base Erosion and Profit Shifting, drawn up in Paris on 24 November 2016, http://orka.sejm.gov.pl/Druki8ka.nsf/0/39B2431FBC225D03C12581670038E84D/\%24File/1776.pdf [access: 11.02.2018].

The Protocol between the Republic of Poland and the Swiss Confederacy on the Amendment of the Convention the Republic of Poland and the Swiss Confederacy on Avoiding Double Taxation in Matters of Income and Capital concluded in Bern as of 2 September 1991 and the Protocol drawn up in Bern as of 2 September 1991 made in Warsaw as of 20 April 2010 (Journal of Laws 2011, No. 255, Item 1533). 
Transfer Pricing Documentation and Country-by-Country Reporting, Action 13 - 2015 Final Report, www.keepeek.com/Digital-Asset-Management/oecd/taxation/transfer-pricing-documentation-and-country-by-country-reporting-action-13-2015-final-report_9789264241480-en\#. WeIpTGi0PIU [access: 10.05.2018].

Wieśniak-Wiśniewska A., Czerwiński M., Świat podatków po projekcie BEPS i jego wptyw na polskich podatników, „Przegląd Podatkowy” 2016, nr 6.

www.oecd.org/tax/automatic-exchange/international-framework-for-the-crs/multilateral-competent-authority-agreement.pdf [access: 10.05.2018].

www.oecd.org/tax/automatic-exchange/news/first-automatic-crs-exchanges-between-49-jurisdictions-to-take-place-over-2000-bilateral-exchange-relationships-in-place.htm [access: 10.05.2018].

Wykaz umów o unikaniu podwójnego opodatkowania, www.finanse.mf.gov.pl/pl/abc-podatkow/umowy-miedzynarodowe/wykaz-umow-o-unikaniu-podwojnego-opodatkowania/-/asset_publisher/ d3oA/content/wykaz-umow-o-unikaniu-podwojnego-opodatkowania?_101_INSTANCE_d3oA_ redirect=http $\% 3 \mathrm{~A} \% 2 \mathrm{~F} \% 2 \mathrm{Fwww}$.finanse.mf.gov.pl\%2Fpl\%2Fabc-podatkow $\% 2$ Fumowy-miedzynarodowe\%2Fwykaz-umow-o-unikaniu-podwojnego-opodatkowania\%3Fp_p_id\%3D101_ INSTANCE_d3oA\%26p_p_lifecycle $\% 3 \mathrm{D} 0 \% 26 \mathrm{p} \_p \_s t a t e \% 3$ Dnormal $\% 26 \mathrm{p} \_p \_m o-$ de\%3Dview\%26p_p_col_id\%3Dcolumn-2\%26p_p_col_count\%3D1\&_101_INSTANCE_d3oA_ cur $=0 \&$ page $=2 \# p \_p \_i d \_101 \_I N S T A N C E \_d 30 A \_$[access: 11.03.2108].

Wykaz umów o wymianie informacji w sprawach podatkowych, www.finanse.mf.gov.pl/pl/abc-podatkow/umowy-miedzynarodowe/wykaz-umow-o-wymianie-informacji-w-sprawach-podatkowych [access: 11.03.2018].

\section{STRESZCZENIE}

Żadne z działań przewidzianych w projekcie BEPS nie odwołuje się bezpośrednio do zintensyfikowania wymiany informacji podatkowych. Opracowując projekt BEPS, OECD zidentyfikowała przestrzenie prawa podatkowego, w których dostrzeżono potrzebę wprowadzenia konkretnych zmian. Cele wskazane w projekcie BEPS nie zostaną jednak osiągnięte bez znaczącej poprawy przepływu informacji podatkowych pomiędzy administracjami podatkowymi poszczególnych państw.

Od kilku lat można zaobserwować istotny przełom w obszarze wymiany informacji podatkowych. Po pierwsze, coraz większe znaczenie mają umowy o wymianie informacji podatkowych, zawierane z zasady z jurysdykcjami stosującymi szkodliwą konkurencję podatkową. Po drugie, znacząco wzrosła rola wielostronnej umowy o wzajemnej współpracy administracyjnej w sprawach podatkowych, przewidującej możliwość wymiany informacji podatkowych. Po trzecie, z samego projektu BEPS wynika potrzeba zintensyfikowania działań w zakresie wymiany informacji podatkowych. W działaniu 5, poświęconym przeciwdziałaniu szkodliwym praktykom podatkowym, wskazano na potrzebę poprawy transparentności z uwzględnieniem obowiązkowej wymiany spontanicznej dotyczącej rozstrzygnięć związanych z uzyskaniem preferencyjnych zasad opodatkowania, natomiast wdrożenie celów opisanych w działaniu 13 wymaga rozwoju automatycznej wymiany informacji podatkowych. Wobec powyższego nie ulega wątpliwości, że skuteczna wymiana informacji podatkowych stanowi jedno z narzędzi, bez których realizacja założeń projektu BEPS będzie znacząco utrudniona.

Slowa kluczowe: podatek; unikanie opodatkowania; wymiana informacji podatkowych; projekt BEPS 